\title{
Benthic Foraminifera in Eastern Bahrain: Relationships With Local Pollution Sources
}

\author{
Muhammad Arslan ${ }^{1 *}$, Michael A. Kaminski ${ }^{1 * *}$, Amjad Khalil2, \\ Muhammad Ilyas ${ }^{3}$, Bassam S. Tawabini ${ }^{1}$ \\ ${ }^{1}$ Geosciences Department, College of Petroleum Engineering and Geosciences, \\ King Fahd University of Petroleum and Minerals, \\ PO Box 701, Dhahran, 31261, Saudi Arabia \\ ${ }^{2}$ Life Sciences Department, King Fahd University of Petroleum and Minerals, \\ PO Box 701, Dhahran, 31261, Saudi Arabia \\ ${ }^{3}$ Research Institute, King Fahd University of Petroleum and Minerals, \\ Dhahran, 31261, Saudi Arabia
}

Received: 13 November 2016

Accepted: 29 December 2016

\begin{abstract}
This preliminary study tracks the response of living benthic foraminifera at a polluted site in eastern Bahrain, with the aim to determine the effects of recent anthropogenic pollution on their distribution patterns and morphological deformities. The boat harbor in Askar, Bahrain is subjected to pollution by nutrients, organic matter, and hydrocarbons. Foraminiferal density is found to be higher at the polluted site compared with a nearby unpolluted site, suggesting a possible higher amount of available nutrients for the benthic foraminifera. Seven taxonomical groups were recognized in the polluted transect, including Ammonia, Glabratellina, Murrayinella, Elphidium, Brizalina, miliolids, and peneroplids. By comparing the foraminiferal assemblages with a nearby unpolluted transect, the genus Murrayinella appeared to be a dominant and pervasive taxon, as it was able to proliferate in the organically polluted environment. The results are contradictory to previously published findings on modern foraminiferal assemblages in the Arabian Gulf, as Murrayinella is rarely reported. However, the population of miliolids was drastically reduced at the polluted site due to high organic matter pollution, which might support the sensitive nature of this taxonomic group. In any case, the miliolids can be considered as a pollution proxy for future biomonitoring studies in the region.
\end{abstract}

Keywords: Arabian Gulf, pollution, benthic foraminifera, foraminiferal density, Glabratellina, Murrayinella

*e-mail: kaminski@kfupm.edu.sa

**e-mail: arsilan324@gmail.com 


\section{Introduction}

Benthic foraminifera have been widely exploited as bio-indicators for the environmental quality assessment of marine ecosystems [1-3]. Their distributional patterns are influenced by natural marine environmental conditions and by the possible presence of different sources of pollution [4]. Benthic foraminifera might respond to adverse environmental conditions in terms of abundance and diversity changes, the appearance of opportunistic taxa, changes in foraminiferal assemblage composition, and morphological abnormalities [5-6].

Many studies have documented increased numbers of foraminiferal tests in organic-rich areas [7-9]. In fact, benthic foraminifera might benefit from the presence of organic matter that directly represents a source of food and might indirectly reduce predation and/or competition, particularly when sediments experience oxygen deficiency [10]. The availability of organic material and its quality promote an increase in the overall foraminiferal density [8]. However, excess organic matter may lead to oxygen deficiency with the consequence of the disappearance of the most sensitive taxa, an increase in opportunistic taxa, a decrease in diversity, and a change in microhabitat succession [11]. As a consequence, an increased flux of organic matter may cause an alteration of natural foraminiferal assemblages [12]. In addition to foraminiferal density, oxygen-deficient environments can also limit foraminiferal diversity [13]. As in other marine groups, several species have been found to be tolerant or opportunistic to various pollution sources, including organic matter, heavy metals, and chemicals [14]. Based on such criteria, a distinction has been developed to differentiate pollution-tolerant taxa from pollution-sensitive taxa [15]. A previous seasonal survey of living benthic foraminifera in a relatively unpolluted site offshore in eastern Bahrain revealed the maximum foraminiferal density (FD) during the winter season, attributed to an increased number of juveniles [16]. A pronounced seasonality effect in the benthic foraminiferal populations has also been observed. The proportion of juveniles increased in the offshore direction. The current preliminary study is a follow-up to this previous study and aims to document the response of benthic foraminiferal assemblages in a polluted transect and compare it with a nearby unpolluted locality. To the best of our knowledge, this is the first report of its kind from the eastern coastline of the Kingdom of Bahrain in the Arabian Gulf.

\section{Materials and Methods}

\section{Study Area and Sampling Strategy}

The study was conducted in a polluted transect next to the boat harbor in the town of Askar on the eastern coast of Bahrain in the Arabian Gulf $\left(26^{\circ} 14^{\prime} 13.811^{\prime \prime} \mathrm{N}, 50^{\circ} 34^{\prime} 5.158^{\prime} \mathrm{E}\right)$. The sea floor in the area is characterized by carbonates with fine to coarsegrained sediments. The offshore coastal area is microtidal $(<1 \mathrm{~m})$ with a diurnal rhythm [16]. The foreshore is wide and slopes very gently, and is characterized by silty, sandy carbonate sediments. The water temperature varies between $17^{\circ}$ and $31^{\circ} \mathrm{C}$, and salinity is approximately 45-46 throughout the year. Recently, boat traffic and a)

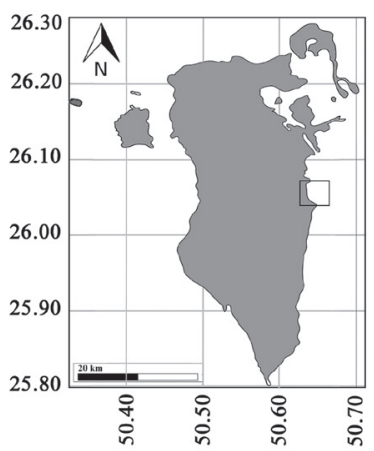

c)

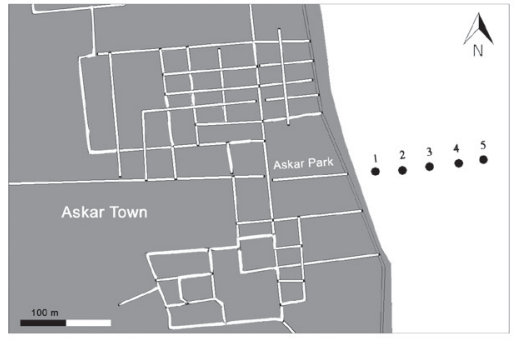

b)

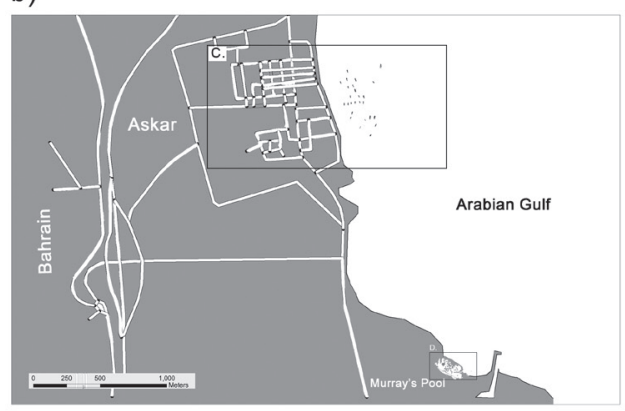

d)

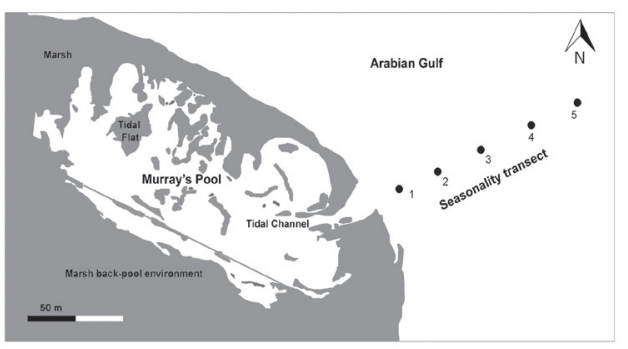

Fig. 1. Geographical context of polluted and unpolluted transects in the Arabian Gulf: a) location map showing study area in eastern Bahrain, b) polluted and unpolluted transects in eastern Bahrain, c) the polluted transect along the boat harbor, and d) the unpolluted transect along Murray’s pool. 
domestic sewage discharge has resulted in the deterioration of environmental quality of the site (Fig. 1).

Sampling was performed during winter (29 January 2015) and five samples were collected from the transect in the offshore direction. The selection of season has been primarily based on our previous findings, where the highest standing crop was found in winter [16]. The bottom water and sediment samples were collected from the coastline to $250 \mathrm{~m}$ offshore, from water depths of $0.4 \mathrm{~m}$ to $1.0 \mathrm{~m}$. The transect was compared with a nearby one in an unpolluted site previously studied by Arslan et al. [16].

Water was collected by dipping well-rinsed glass jars at each station prior to sediment sampling to avoid any alteration of physicochemical parameters. Sediment samples with a depth of $1.0 \mathrm{~cm}$ (volume $\sim 57.6 \mathrm{~cm}^{3}$ ) were collected with a spatula (taking care not to disturb the sediment floor) and placed into plastic storage boxes fitted with a lid that was secured under ambient seawater. A layer of aluminum foil was placed over the jar mouth to avoid sediment contact with the plastic cap. Both water jars and sediments boxes were transported to the laboratory on the same day for analyses. Sample processing was carried out at the Research Institute and Environmental Sciences labs at King Fahd University of Petroleum and Minerals (Saudi Arabia). Both sediment and water samples were preserved at $4^{\circ} \mathrm{C}$ until analyses were performed.

\section{Physicochemical Parameters of Water}

Salinity, conductivity, temperature, dissolved oxygen, total dissolved solids, and $\mathrm{pH}$ were measured in situ using a YSI multi-probe water monitoring unit (YSI, USA).

\section{Eutrophication Pollution Analysis}

The eutrophication indicators $\left(\mathrm{SO}_{4}^{-2}, \mathrm{PO}_{4}^{-2}, \mathrm{NO}_{3}\right.$, and $\mathrm{NO}_{2}^{-}$) were measured in the laboratory using ion chromatography (IC-Metrohm 850 Professional system, Switzerland). The seawater samples were prepared by performing 1,000-fold dilution in ultra-pure water. Prior to analysis, standard solutions of $10 \mathrm{ppm}$ concentration were prepared for each ion and then injected into the system to assess the performance and calibration of the instrument [17].

\section{Grain Size Analysis}

The grain-size distribution of sediments along depth transect was determined as per the ASTM D422 guidelines (astm.org/Standards/D422). Samples were first treated with an $\mathrm{H}_{2} \mathrm{O}_{2}$ solution to remove the organic matter. The analysis was then performed by taking 50 grams of each sample followed by manual sieving and drying at $60^{\circ} \mathrm{C}$. The grain size distributions were statistically and graphically summarized to understand the porosity and permeability for later analysis as per the guidelines of ASTM, 1984 (astm.org/DIGITAL_LIBRARY/STP/ PAGES/STP30216S.htm).

\section{Total Organic Carbon}

The total organic carbon (TOC) analysis was performed as per the EPA 415.1/9060 standard method [Ref.]. Approximately $200 \mathrm{mg}$ of the dried and ground sample was weighed and placed in ceramic boats. The sample was suspended in a diluted hydrochloric acid solution thrice a day to break down all the carbonates present in the sample, resulting in the removal of total inorganic carbon (TIC). Finally, the suspensions were injected and analyzed for TOC content in a Shimadzu TOC-Vcsh Total Organic Carbon Analyzer. The standards and samples were weighed in duplicate, and five calibration points were taken to construct a calibration curve.

\section{Heavy Metals Analysis}

In order to determine the heavy metal contents in the sediments, $5 \mathrm{~g}$ of each sample was dried under a light bulb at low temperature to prevent the evaporation of heavy metals, then reduced to fine powder. Thereafter, the heavy metals content was investigated in all samples by Activation Laboratories Ltd. (Ontario, Canada; actlabs. com). The samples were analyzed for 63 elements using inductively coupled plasma mass spectrometry (ICP/ MS). $0.5 \mathrm{~g}$ of the sample material was digested in aqua regia $\left(0.5 \mathrm{ml} \mathrm{H}_{2} \mathrm{O}, 0.6 \mathrm{ml}\right.$ concentrated $\mathrm{HNO}_{3}$, and $1.8 \mathrm{ml}$ concentrated $\mathrm{HCl}$ ) at $90^{\circ} \mathrm{C}$ for 2 hours. Digested samples were diluted and analyzed by Perkin Elmer Sciex ELAN $9000 \mathrm{ICP} / \mathrm{MS}$.

\section{Hydrocarbon Analysis}

Total hydrocarbons content (THC) of the samples was determined using EPA 8015/3510 standard method while the poly aromatic hydrocarbons (PAHs) were measured as per the EPA 3510/8040/610/8310 standard methods. Initially, hydrocarbon extraction from the sediments was performed using the Dionex accelerated solvent extraction system (ASE 200), a new procedure that extracts organic solvents at high temperature and pressure above the boiling point as described as Method 3545 in U.S. EPA SW-846. Representative samples of $5 \mathrm{~g}$ of sediment from each station were taken and homogenized equally with commercially available hydrant for removal of water content to perform the analysis. The mixture was directly enclosed in the sample cells, which were subsequently installed on the system to statically extract the hydrocarbons under $100^{\circ} \mathrm{C}$ and 500 psi pressure for 20 min. Finally, compressed gas allowed for the extraction of hydrocarbon from the sample cell to the collection vessel using n-hexane. For quality control, samples were run in duplicate and surrogate spiking was performed to assess extraction efficiency.

Analyses of the extracts were performed using an Agilent 7890A gas chromatography flame ionization detector (GC/FID). Separations were performed using a $30 \mathrm{~m} \times 0.32 \mathrm{~mm}$ internal diameter Varian capillary column. The carrier gas used was helium with column flow rate of 
$25 \mathrm{~mL} / \mathrm{min}$, and the pressure was regulated by hydrogen and air flowing at rates of $30 \mathrm{~mL} / \mathrm{min}$ and $300 \mathrm{~mL} / \mathrm{min}$, respectively. The initial column temperature was set at $60^{\circ} \mathrm{C}$ for $1 \mathrm{~min}$, and then increased to $150^{\circ} \mathrm{C}$ at $10^{\circ} \mathrm{C} / \mathrm{min}$ for $12 \mathrm{~min}$. The detector temperature was maintained at $200^{\circ} \mathrm{C}$. Peaks were integrated using a Chrom Card system (CE Instruments). Finally, quantification of THC was performed using a hydrocarbon window of C10 to C36 calibration standards.

\section{Benthic Foraminifera Analysis}

In the laboratory, $5 \mathrm{~cm}^{3}$ of sediment was taken from each box. The sample was sieved through a $63 \mu \mathrm{m}$ mesh sieve, and the sediment split using a wet-microsplitter to ensure statistically meaningful counts of living individuals. Each sample was washed carefully with natural seawater. Finally, the entire residue was microscopically analyzed and the total numbers of living foraminifera (both adults and juveniles) were picked under a reflected-light binocular microscope based on the presence of protoplasm. We distinguished visually between "living" (protoplasm-full) and "dead" (protoplasm-empty) as described previously $[16,18]$. Assemblage parameters including the adult/ juvenile ratio (individuals with diameter less than 150 $\mu \mathrm{m}$ were considered juveniles), foraminiferal density (FD, number of living individuals), and generic diversity indexes (richness, H' and Fisher- $\alpha$ ) were calculated. Foraminifera were taxonomically identified at the genus level using the monographs of Hottinger et al. [19], Loeblich and Tappan [20] and Hayward et al. [21]. As the current study attempts to compare the foraminiferal density with the data published by Arslan et al. [16], we did not attempt to resolve species taxonomy.

\section{Statistical Analyses}

Prior to statistical analyses, all the available biotic and abiotic data of the two transects (polluted: $\mathrm{P}$ and unpolluted: UP) were logarithmically transformed $\log (1+\mathrm{X})$ and tested for normality through the Kolmogorov-Smirnov test. As most of the variables fail for normality, nonparametric statistics were applied. The Mann-Whitney U test, a nonparametric test, was used to check for significant differences between the two transects for any parameters $(\mathrm{p}<0.01)$ [22]. In order to evaluate the relationships among variables, a correlation matrix (Spearman's rho) was calculated for all the biotic and abiotic data. These two analyses were performed in Statistica v. 6.0. Non-metric multi-dimensional scaling (nMDS) ordinations derived from Bray-Curtis similarity matrices were used to document the differences among the two transects in the abiotic parameters and in the benthic foraminiferal assemblages. Furthermore, the significance of the differences in either the benthic foraminiferal assemblages and/or abiotic parameters was tested by means of the analysis of similarity (one way ANOSIM). In order to define the contribution of each biotic and abiotic parameter to the observed is the similarity between the two transects using a SIMPER (similarity percentages) analysis. For this analysis, a fourth-root transformation of the data was applied. The nMDS, ANOSIM, and SIMPER analyses were carried out in PRIMER v. 5.2.9.

\section{Results}

\section{Environmental Characterization of the Two Transects}

Physicochemical parameters of water showed minor variations between the sampling stations and the two transects. Accordingly, salinity ranged between 43.9 and 45.9 (45.4 \pm 0.7$)$, and temperature varied between 20.1 and 21.8 (20.9 \pm 0.8$)$ (Table 1S). Results of grain size analysis revealed the prevalence of medium-grained sand followed by fine sand (i.e., $43.5 \%$ and $40.8 \%$, respectively). The coarser sand fraction increased in the seaward direction, whereas the fine fraction (silt and clay) diminished (Table 1S). Further examination of coarser particles under a stereomicroscope revealed that the fraction size $>63 \mu \mathrm{m}$ was mainly constituted by reworked bioclasts.

The level of nitrates was higher in the polluted Askar boat harbour than at the unpolluted site, without any significant trend along the transect, whereas sulfate showed an opposite pattern (Table 2S). The TOC averaged $10,448 \mathrm{mg} / \mathrm{kg}(=1.05 \%)$ in the polluted transect, which is higher than at the unpolluted one $(7,296 \mathrm{mg} / \mathrm{kg}$ ) (Table 2S). Similarly, THC was also found to be higher in the polluted transect (average of $67.37 \mathrm{mg} / \mathrm{kg}$ ) than in the unpolluted one $(2.24 \mathrm{mg} / \mathrm{kg}$ ). Compared to the ER-L (effect range low) and ER-M (effect range - median) values reported for the United States Environmental Protection Agency's (USEPA) sediment guidelines, none of the considered heavy metals were beyond the permitted standards in either transect, except strontium (Supplementary Material 2 ). The concentration factor (CF) of selected heavy metals (Cr, Ni, Cu, Zn, As, Ag, Cd, Hg, V, Mn, Fe, Co, and Pb) and the pollution load index (PLI) were calculated following Martins et al. (2013).

\section{Benthic Foraminifera}

All the studied samples from both transects contained abundant and well-preserved living benthic foraminifera. The overall FD was higher in the polluted Askar boat harbour than in the unpolluted transect. More specifically, FD varied between 176 to 309 individuals (average of 254) in the polluted transect, whereas in the unpolluted transect FD ranged between 62 and 215 individuals (average of 153). Furthermore, the polluted transect showed an increase of FD up to the third station and then decreasing values, whereas the unpolluted exhibited a clear increasing trend seaward (Table 3S). In addition, an opposite trend of juveniles was observed where a gradual decrease was found for the polluted transect and a steady increase for the unpolluted one (Table 3S). Seven groups (i.e., Ammonia, Glabratellina, Murrayinella, 
Elphidium, Brizalina, miliolids, and Peneroplidae) were identified in the polluted transect, with the addition of the genus Murrayinella, which was absent in the unpolluted transect (Table 3S). Considering the relative abundance in all samples, the most abundant groups in the polluted transect were Ammonia, Glabratellina, and Murrayinella, whereas the unpolluted transect was mainly characterized by Ammonia, Glabratellina, and miliolids. Ammonia was consistently present in both transects and dominant, representing $35.1 \%$ on average in the foraminiferal assemblages of the polluted transect, which is somewhat lower compared with the unpolluted transect $(41.5 \%$ on average). The second most abundant group was the Glabratellina, which represented $30.7 \%$ of the living assemblage in the polluted transect and was slightly less abundant in the unpolluted transect (26.0\%). Miliolids were significantly less abundant in the polluted transect compared with the unpolluted transect, representing $1.8 \%$ and $28.3 \%$ of the living assemblages, respectively (Table 3S). The dominance of Ammonia and Glabratellina was nearly constant in both the polluted and unpolluted transects with no specific trend. Murrayinella was observed only in the polluted transect, the relative percentage of which increased up to the third station and then decreased in the more seaward direction. By contrast, miliolids were abundant in the unpolluted transect with increasing population in the offshore direction, whereas their numbers were significantly reduced in the polluted transect with the exception of station 1 (Table $3 \mathrm{~S})$. However, due to their lower numbers in the polluted transect, it is difficult to compare and correlate their transect behaviors with the unpolluted transect. Elphidium represents a minor component of the living assemblages in both transects, and its abundance is relatively higher in the nearshore stations and decreased in the offshore direction.

The Shannon-Weaver H' values showed opposite trends with respect to each transect. The highest H'values were observed at station 1 in the polluted transect and a gradual decrease was observed along the transect length. On the other hand, in the unpolluted transect, lowest H' values were observed in station 1 , and $\mathrm{H}^{\prime}$ values increased gradually in the offshore stations. By contrast, higher values of Fisher- $\alpha$ were observed at the nearshore stations for both polluted and unpolluted transects; however, the value was highest in the third station for polluted transect and at the second station in the unpolluted transect. The results of richness illustrate no significant variations in each transect, whereas high evenness values are observed in nearshore stations, and values decreased horizontally for both transects (Table 3S).

\section{Statistical Analysis}

Results of the Mann-Whitney U Test show substantial differences between the two transects. More specifically,

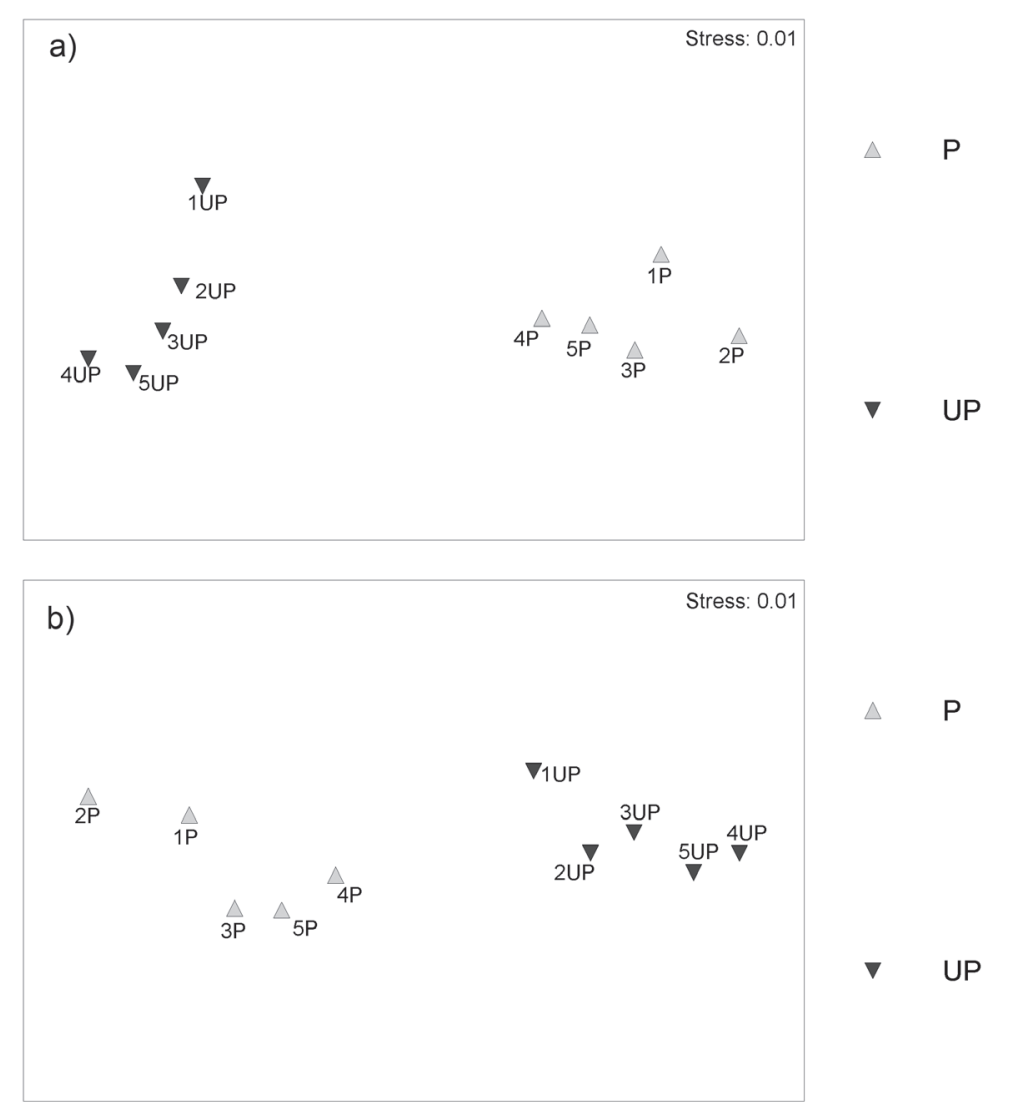

Fig. 2. The non-metric multidimensional scaling (nMDS) ordination for polluted and unpolluted transects: a) nMDS considering all variables and $b$ ) nMDS considering foraminifera. 
A

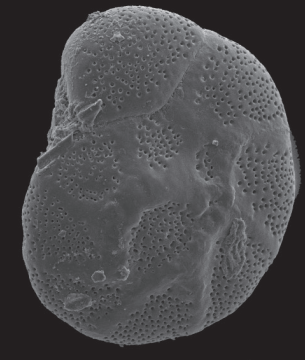

$\overline{50 \mu \mathrm{m}}$
B



C

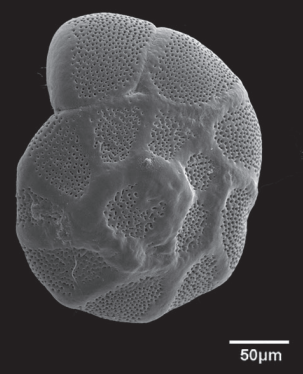

D

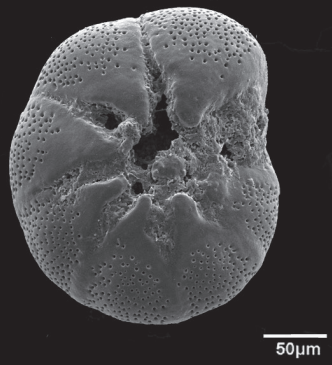

G

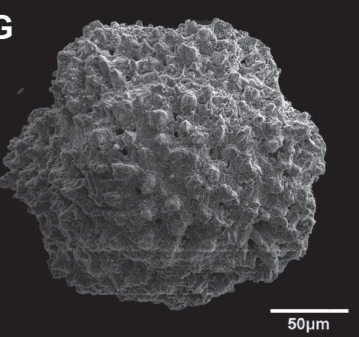

H

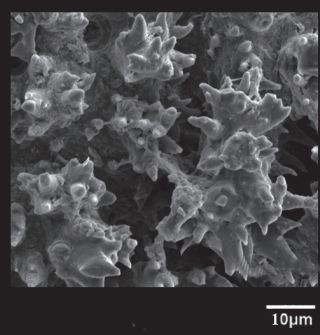

K

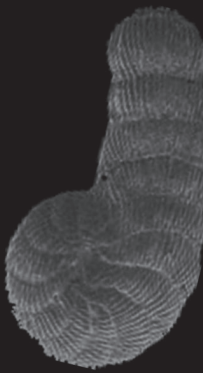

$\overline{50 \mu \mathrm{m}}$

L

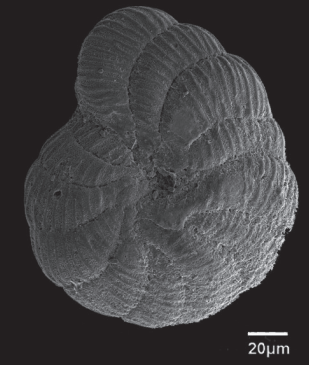

M



$\mathbf{N}$

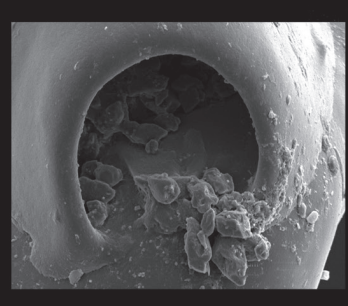

o


$\mathbf{R}$
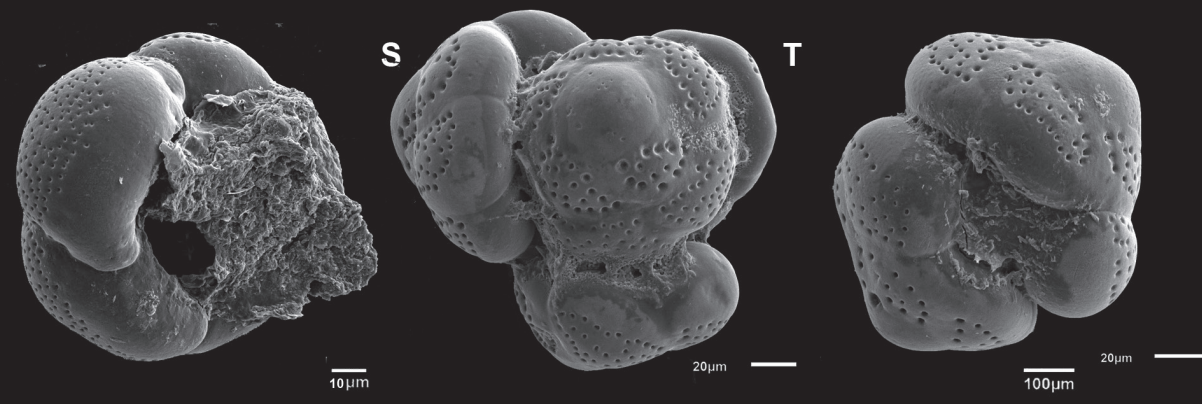

Plate 1. Scanning electron micrographs of the selected foraminiferal specimens. A, C. Ammonia cf. A. parkinsoniana (dorsal view) B, D. Ammonia cf. A. parkinsoniana (ventral view) E, G. Murrayinella sp.1 (dorsal view), F Murrayinella sp.1 (ventral view); H. Murrayinella sp.1 spicules (closer view) I. Coscinospira sp. 1; J. Peneroplis proteus; K, L. Monalysidium sp. 1; M, N. Quinqueloculina cf. seminula (front view); O. Elphidium advenum (dorsal views); P. Elphidium advenum (closer view); Q, Glabratellina sp. 1; R. Glabratellina sp. 1 (post-plastogamic specimen); and S, T. Glabratellina sp. 1 (plastogamic clusters). 


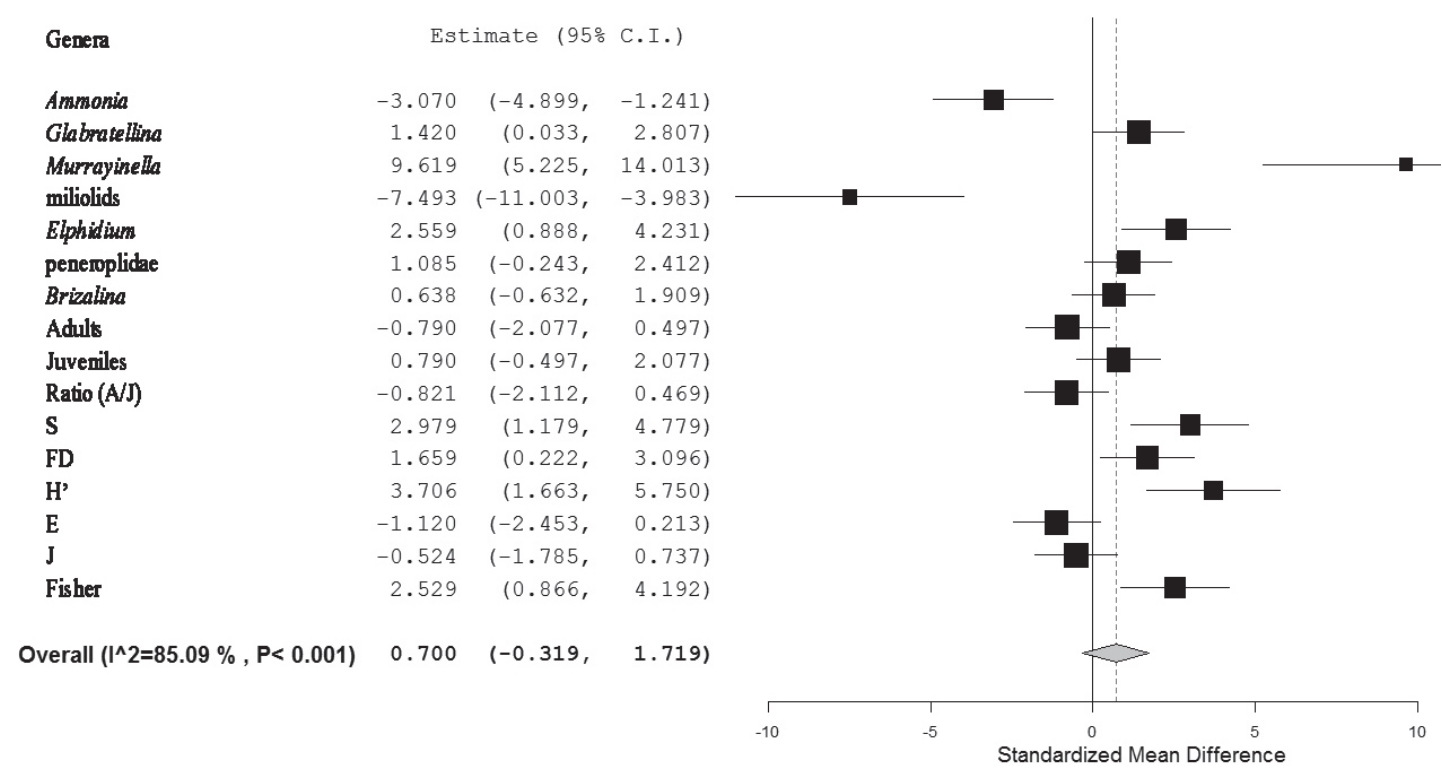

Fig. 3. Comparison of two transects illustrated by Forest Plot: the horizontal bars touching central mea reflect no statistical differences among the transects for the corresponding species.

the parameters of temperature, $\mathrm{pH}$, fine sand, medium sand, nitrates, sulfates, THC, $\mathrm{Cr}, \mathrm{Cu}, \mathrm{As}, \mathrm{Pb}, \mathrm{CF}, \mathrm{PLI}$, Ammonia, Murrayinella, miliolids, Elphidium, S, H', and Fisher- $\alpha$ index are significantly different between the polluted and the unpolluted transects $(p<0.01)$ (Table 4S). Spearman's rho correlation analysis shows significant correlation among major abiotic and biotic variables $(\mathrm{P}<0.05)$ (Table $5 \mathrm{~S})$. Regarding abiotic factors, TOC, THC, and selected trace elements such as $\mathrm{Cr}, \mathrm{Cu}$, $\mathrm{As}, \mathrm{V}, \mathrm{Mn}, \mathrm{Fe}$, and $\mathrm{Pb}$ are strongly positively correlated with the fine grain substrate (i.e., silt and clay, fine sand), whereas a strong negative correlation is observed with the medium grain substrate (medium sand). It is important to mention here that the majority of abiotic factors did not show strong correlation with coarse-grained substrate except for a few trace elements $(\mathrm{V}, \mathrm{Mn}, \mathrm{Fe}$, and $\mathrm{Co})$ that show a strong negative correlation with coarser particles.

For biotic factors, Ammonia and miliolids are found to be strongly negatively correlated with the fine-grained substrate, strongly positively correlated with the mediumgrained substrate, and weakly positively correlated with the coarse-grained substrate. In contrast, Murrayinella and Elphidium showed strong positive correlation with the fine-grained substrate, strong negative correlation with the medium-grained substrate, and weak negative correlation with the coarse-grained substrate. Glabratellina and Brizalina did not show any strong correlation with the substrate parameters, but a moderate positive correlation was found with the fine-grained substrate, a moderate negative correlation was found with the medium-grained substrate, and a moderate to weak negative correlation was found with the coarse-grained substrate. Additionally, peneroplids showed weak negative correlation with silt and clay, weak positive correlation with the fine sand, weak negative correlation with the medium sand, and moderate positive correlation with the coarse sand.
In addition, correlation analysis with nitrates, sulfates, TOC, and THC were also performed. Strong negative correlations were observed for Ammonia and miliolids with nitrates and THC, whereas a strong positive correlation was found for Glabratellina, Murrayinella, and Elphidium. For sulfates, Murrayinella, Elphidium, and peneroplids showed strong negative correlation and Ammonia showed strong positive correlation. Lastly, TOC had strong positive correlation with Murrayinella, but strong negative correlation with miliolids.

The nMDS, which simultaneously considers all the variables, separated the samples into two distinct groups (stress 0.01) that reflect the transect either when all variables or foraminiferal ones are considered (Fig. 2). The separation of the two groups is significant as revealed by ANOSIM $(p<0.001, R=0.98)$ either for all variables or for aminiferal ones. The SIMPER analysis applied to abiotic parameters reveals that ca. $13.1 \%$ of dissimilarity between the two transects and identifies $\mathrm{CF}$, THC, sulfates, $\mathrm{Pb}, \mathrm{PLI}$, and TOC as the parameters most responsible for this dissimilarity (Table 6S). On the other hand, the average dissimilarity of foraminiferal variables is $10.9 \%$ and is mainly due to Murrayinella, miliolids, and FD (Table 7S).

\section{Discussion}

The current study attempts to explain the assessment of local pollution sources on benthic foraminiferal assemblages at a polluted locality in eastern Bahrain along with its comparison with a nearby unpolluted locality. Both of the localities reflect the same environmental conditions and substrate parameters, as the distance between both localities is less than $1 \mathrm{~km}$. The unpolluted locality was initially investigated by Arslan et al. [16], in 
which six foraminiferal groups (Ammonia, Glabratellina, Elphidium, miliolids, peneroplids, and Brizalina) were observed along with no background pollution, i.e., heavy metals, hydrocarbons, and organic matter. Moreover, Brizalina was found to be a seasonal genus as it was only present during spring and autumn.

In the polluted transect, the overall concentrations of pollutants - particularly organic carbon, hydrocarbons, and trace elements in the sediment samples - were found to be significantly higher compared with the unpolluted transect. The relatively high concentrations of pollutants could be attributed to boat traffic, domestic sewage discharge, and waste coming from mariculture (i.e., the National Mariculture Center). In addition, the biological decomposition of sewage waste produces biological nutrients, especially nitrates, along with liberation of organic carbon under aerobic conditions [23]. It has been well-established that the distribution of foraminifera in coastal environments is a function of nutrients, organic matter, and hydrocarbons as well as other physicochemical parameters [24]. The high standing crop in the polluted transect could be due to the higher availability of biodegradable organic matter that might have promoted the increase of the foraminiferal population [8, 9, 25]. Accordingly, some studies indicate that the organic matter favors higher foraminiferal populations directly by providing food and indirectly by reducing predation and/or competition [26]. The presence of plastogamic clusters of living foraminifera in the sampled stations might suggest a possible effect of organic carbon as well as seasonality effect (Plate 1) [18]. The highest FD values in the third station with a gradual decrease in both directions might be attributed to the THC.

The presence of seven foraminiferal taxa with the addition of the genus Murrayinella in the polluted transect suggest its appearance, possibly, as an opportunistic pervasive taxon in the organically polluted environment as it can tolerate eutrophic environments and can withstand fluctuating temperatures, turbidity, and salinities [27]. However, other factors may also be responsible for its appearance in the region, but available limited information cannot lead to appropriate deduction. Besides, strong correlations of Murrayinella with nitrates, sulfates, TOC, and THC might suggest the opportunistic behavior of the taxon. Taxonomically, the species appears to be a variety of Murrayinella murrayi, whose occurrence in the Arabian Gulf is of a pervasive nature [28]. The genus has been reported as of lower abundance $(<12 \%)$ from the Abu Dhabi coastline, and throughout those observed in the Pleistocene samples, even in samples with few other taxa. Nevertheless, the genus has not been recorded and catalogued by Cherif et al. [29] and Saidova [30], even under a different name such as Glabratella or Pararotalia. Over and above, no modern examples of an assemblage dominated by Murrayinella has been ever reported from the Arabian Gulf, although the taxon is common throughout the sub-tropical to tropical Indo-Pacific (i.e., northern Australian margin: Chivas et al. [31]; Parker [32]; Japan: Nomura and Takayanagi [33]; Thailand: Melis and Violanti [27]).
Ammonia and Glabratellina were abundant at all the stations of both the polluted and unpolluted transects. This reflects their resistant nature toward high organic matter and supports the finding that some of the rotaliids are capable of surviving and reproducing rapidly in every environment. For instance, some species of the genus of Ammonia such as A. tepida have been reported to have an opportunistic behavior along the Mediterranean coast in the vicinity of a sewage sludge disposal site and other sources of pollution [5, 34, 35]. By contrast, very few miliolids were found in the polluted transect, which suggests that the group is adversely affected by organic pollution when compared with an unpolluted transect [24, 36]. Elphidium, peneroplids, and Brizalina represent a minor component of the living assemblages in both transects, which supports the earlier finding of lower FD in the unpolluted transect [16]. A general comparison of both transects for each foraminiferal group (i.e., genera) can be seen in the forest plot prepared by OpenMEE (Fig. 3).

\section{Conclusions}

Our study concludes that the Askar boat harbor samples contain assemblages dominated by Ammonia, Glabratellina, and Murrayinella in sediments with higher organic matter content. The sediments with high organic matter loadings show a significant reduction of the miliolid population, whereas Murrayinella appeared as a pervasive resistant taxon when compared to the unpolluted transect and previous studies from the Arabian Gulf. Population density is higher at the polluted site, probably due to the higher amount of food available for the benthic foraminifera. A greater proportion of juveniles was found at the unpolluted locality. The foraminiferal distribution is likely to be patchy, and hence our study may not have captured the full range of natural variability. Nevertheless, our observations represent a preliminary investigation, and a future sampling program that focuses on seasonal aspects may unravel additional details. Heterogeneity is always expected based on seasonal variations in the foraminiferal populations and different environmental conditions in each transect.

\section{Acknowledgements}

We thank Fabrizio Fonrtalini for continuous help in manuscript writing and statistical analysis; Eiichi Setoyama and Heinz Scheifinger (formerly from KFUPM) for assistance in the field; and Justin Parker for advice on the taxonomy. We gratefully acknowledge the helpful comments offered by two anonymous reviewers, and financial support from the Deanship of Scientific Research, KFUPM, through research grant IN121028. We further acknowledge the financial support from the Brian J. O’Neill Memorial Scholarship awarded by the Grzybowski Foundation. 


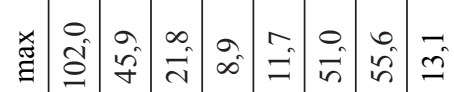

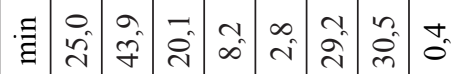

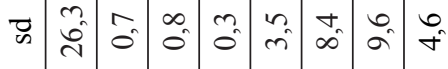

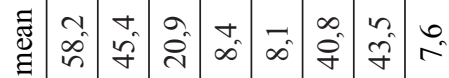

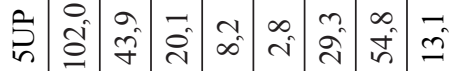

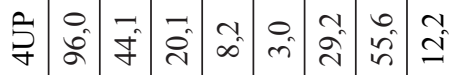

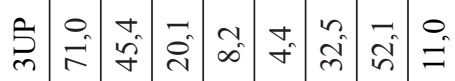



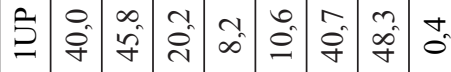

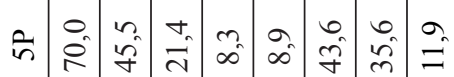

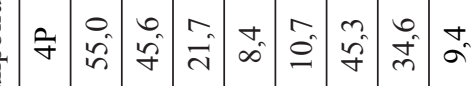

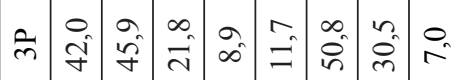



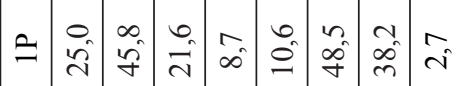

घี อ ๑

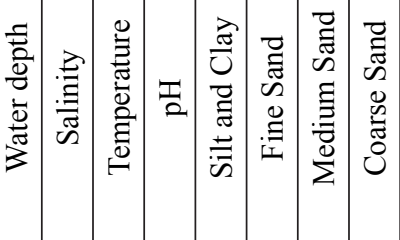

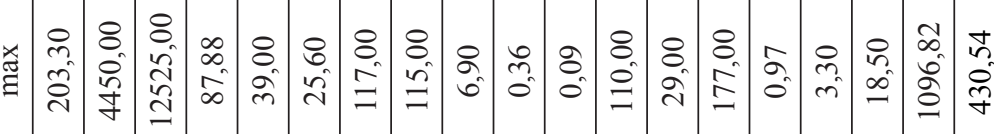

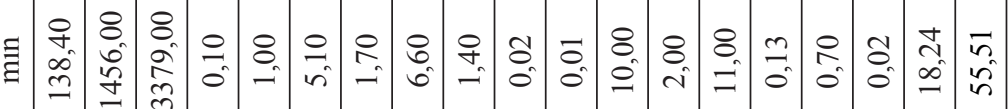

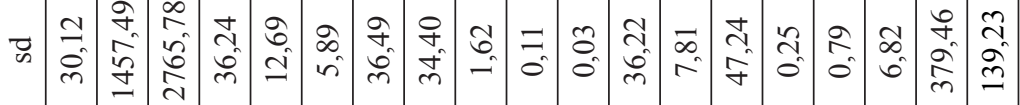

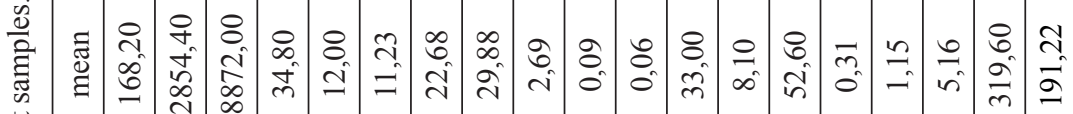
$\overrightarrow{7}$

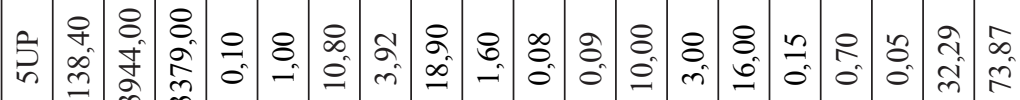



T 88800000000

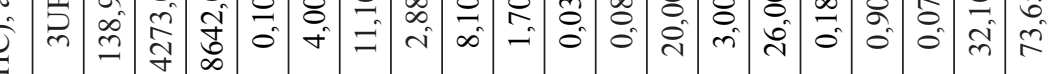

요 8 (8)

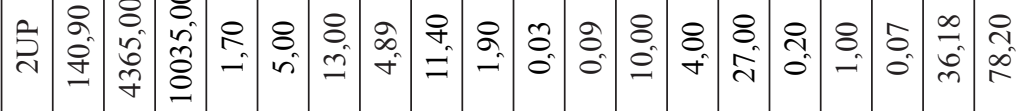
ธี

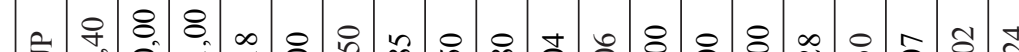

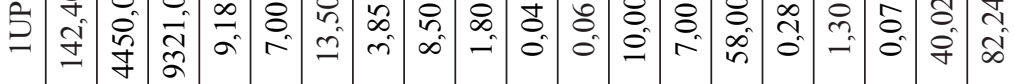

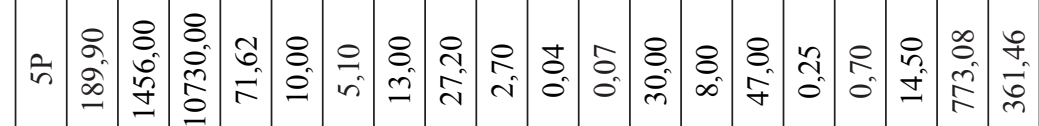

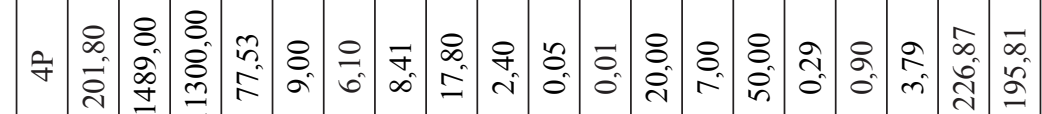

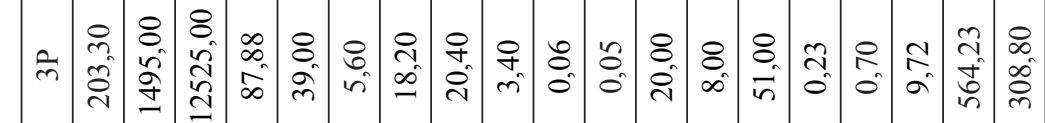

สิ

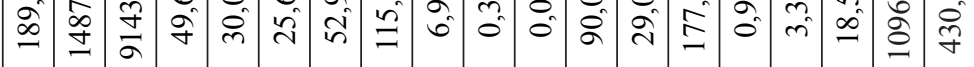

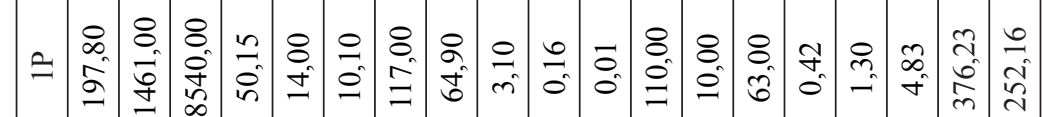



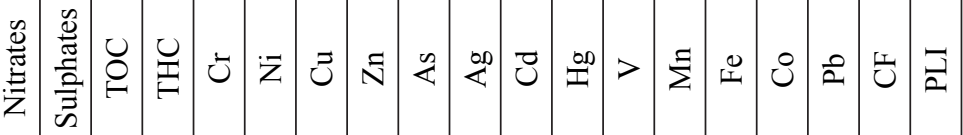




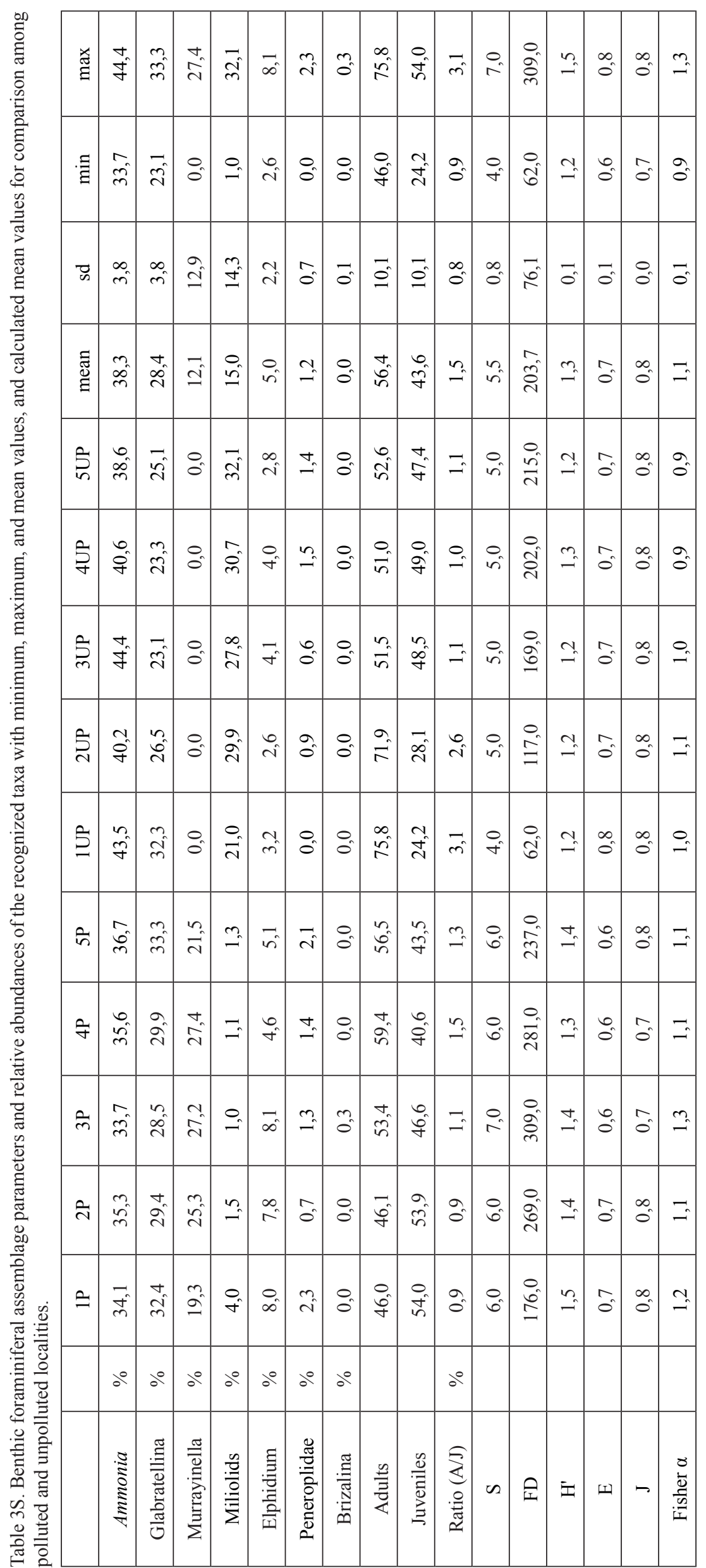


Table 4S. Mann-Whitney U Test comparing single variable at a time.

\begin{tabular}{|c|c|c|c|c|c|c|c|c|c|c|}
\hline \multicolumn{11}{|c|}{ Mann-Whitney U Test By variable Factor Marked tests are significant at $\mathrm{p}<.01000$} \\
\hline & $\begin{array}{l}\text { Rank Sum - } \\
\text { Group } 1\end{array}$ & $\begin{array}{c}\text { Rank Sum - } \\
\text { Group } 2\end{array}$ & $\mathrm{U}$ & $\mathrm{Z}$ & p-level & $\begin{array}{c}Z \text { - } \\
\text { adjusted }\end{array}$ & p-level & $\begin{array}{l}\text { Valid N - } \\
\text { Group } 1\end{array}$ & $\begin{array}{l}\text { Valid N - } \\
\text { Group } 2\end{array}$ & $\begin{array}{c}2 * 1 \text { sided - } \\
\text { exact } \mathrm{p}\end{array}$ \\
\hline Salinity & 35 & 20 & 5 & 1,5667 & 0,117186 & 1,58604 & 0,112731 & 5 & 5 & 0,150794 \\
\hline Temperature & 40 & 15 & 0 & 2,61116 & 0,009024 & 2,70281 & 0,006876 & 5 & 5 & 0,007937 \\
\hline $\mathrm{pH}$ & 40 & 15 & 0 & 2,61116 & 0,009024 & 2,62714 & 0,008611 & 5 & 5 & 0,007937 \\
\hline Silt and Clay & 39 & 16 & 1 & 2,40227 & 0,016294 & 2,40227 & 0,016294 & 5 & 5 & 0,015873 \\
\hline Fine Sand & 40 & 15 & 0 & 2,61116 & 0,009024 & 2,61116 & 0,009024 & 5 & 5 & $\mathbf{0 , 0 0 7 9 3 7}$ \\
\hline Medium Sand & 15 & 40 & 0 & $-2,61116$ & 0,009024 & $-2,61116$ & 0,009024 & 5 & 5 & 0,007937 \\
\hline Coarse Sand & 24 & 31 & 9 & $-0,73113$ & 0,464703 & $-0,73113$ & 0,464703 & 5 & 5 & 0,547619 \\
\hline Nitrates & 40 & 15 & 0 & 2,61116 & 0,009024 & 2,61116 & 0,009024 & 5 & 5 & 0,007937 \\
\hline Sulphates & 15 & 40 & 0 & $-2,61116$ & 0,009024 & $-2,61116$ & 0,009024 & 5 & 5 & 0,007937 \\
\hline TOC & 35 & 20 & 5 & 1,5667 & 0,117186 & 1,5667 & 0,117186 & 5 & 5 & 0,150794 \\
\hline THC & 40 & 15 & 0 & 2,61116 & 0,009024 & 2,6434 & 0,008208 & 5 & 5 & $\mathbf{0 , 0 0 7 9 3 7}$ \\
\hline $\mathrm{Cr}$ & 40 & 15 & 0 & 2,61116 & 0,009024 & 2,61911 & 0,008816 & 5 & 5 & $\mathbf{0 , 0 0 7 9 3 7}$ \\
\hline $\mathrm{Ni}$ & 20 & 35 & 5 & $-1,5667$ & 0,117186 & $-1,5667$ & 0,117186 & 5 & 5 & 0,150794 \\
\hline $\mathrm{Cu}$ & 40 & 15 & 0 & 2,61116 & 0,009024 & 2,61116 & 0,009024 & 5 & 5 & $\mathbf{0 , 0 0 7 9 3 7}$ \\
\hline $\mathrm{Zn}$ & 39 & 16 & 1 & 2,40227 & 0,016294 & 2,40227 & 0,016294 & 5 & 5 & 0,015873 \\
\hline As & 40 & 15 & 0 & 2,61116 & 0,009024 & 2,61116 & 0,009024 & 5 & 5 & 0,007937 \\
\hline $\mathrm{Ag}$ & 36 & 19 & 4 & 1,77559 & 0,075801 & 1,781 & 0,074914 & 5 & 5 & 0,095238 \\
\hline $\mathrm{Cd}$ & 21,5 & 33,5 & 6,5 & $-1,25336$ & 0,210076 & $-1,27679$ & 0,201678 & 5 & 5 & 0,222222 \\
\hline $\mathrm{Hg}$ & 39 & 16 & 1 & 2,40227 & 0,016294 & 2,51117 & 0,012034 & 5 & 5 & 0,015873 \\
\hline V & 39,5 & 15,5 & 0,5 & 2,50672 & 0,012186 & 2,52982 & 0,011413 & 5 & 5 & 0,007937 \\
\hline $\mathrm{Mn}$ & 37 & 18 & 3 & 1,98449 & 0,047203 & 1,98449 & 0,047203 & 5 & 5 & 0,055556 \\
\hline $\mathrm{Fe}$ & 38 & 17 & 2 & 2,19338 & 0,028281 & 2,19338 & 0,028281 & 5 & 5 & 0,031746 \\
\hline $\mathrm{Co}$ & 29 & 26 & 11 & 0,31334 & 0,754023 & 0,3254 & 0,744882 & 5 & 5 & 0,84127 \\
\hline $\mathrm{Pb}$ & 40 & 15 & 0 & 2,61116 & 0,009024 & 2,6434 & 0,008208 & 5 & 5 & 0,007937 \\
\hline $\mathrm{CF}$ & 40 & 15 & 0 & 2,61116 & 0,009024 & 2,61116 & 0,009024 & 5 & 5 & 0,007937 \\
\hline PLI & 40 & 15 & 0 & 2,61116 & 0,009024 & 2,61116 & 0,009024 & 5 & 5 & $\mathbf{0 , 0 0 7 9 3 7}$ \\
\hline Ammonia & 15 & 40 & 0 & $-2,61116$ & 0,009024 & $-2,61116$ & 0,009024 & 5 & 5 & 0,007937 \\
\hline Glabratellina & 37 & 18 & 3 & 1,98449 & 0,047203 & 1,98449 & 0,047203 & 5 & 5 & 0,055556 \\
\hline Murrayinella & 40 & 15 & 0 & 2,61116 & 0,009024 & 2,78543 & 0,005346 & 5 & 5 & $\mathbf{0 , 0 0 7 9 3 7}$ \\
\hline Miliolids & 15 & 40 & 0 & $-2,61116$ & 0,009024 & $-2,61116$ & 0,009024 & 5 & 5 & 0,007937 \\
\hline Elphidium & 40 & 15 & 0 & 2,61116 & 0,009024 & 2,61116 & 0,009024 & 5 & 5 & 0,007937 \\
\hline Peneroplidae & 34 & 21 & 6 & 1,35781 & 0,174526 & 1,35781 & 0,174526 & 5 & 5 & 0,222222 \\
\hline Brizalina & 30 & 25 & 10 & 0,52223 & 0,601509 & 1 & 0,317311 & 5 & 5 & 0,690476 \\
\hline Adults & 24 & 31 & 9 & $-0,73113$ & 0,464703 & $-0,73113$ & 0,464703 & 5 & 5 & 0,547619 \\
\hline Juveniles & 31 & 24 & 9 & 0,73113 & 0,464703 & 0,73113 & 0,464703 & 5 & 5 & 0,547619 \\
\hline Ratio (A/J) & 24 & 31 & 9 & $-0,73113$ & 0,464703 & $-0,73113$ & 0,464703 & 5 & 5 & 0,547619 \\
\hline FD & 38 & 17 & 2 & 2,193378 & 0,028281 & 2,193378 & 0,028281 & 5 & 5 & 0,031746 \\
\hline $\mathrm{S}$ & 40 & 15 & 0 & 2,61116 & 0,009024 & 2,78543 & 0,005346 & 5 & 5 & $\mathbf{0 , 0 0 7 9 3 7}$ \\
\hline $\mathrm{H}^{\prime}$ & 40 & 15 & 0 & 2,61116 & 0,009024 & 2,61116 & 0,009024 & 5 & 5 & 0,007937 \\
\hline E & 19 & 36 & 4 & $-1,77559$ & 0,075801 & $-1,77559$ & 0,075801 & 5 & 5 & 0,095238 \\
\hline $\mathrm{J}$ & 22 & 33 & 7 & $-1,14891$ & 0,250593 & $-1,14891$ & 0,250593 & 5 & 5 & 0,309524 \\
\hline Fisher $\alpha$ & 40 & 15 & 0 & 2,61116 & 0,009024 & 2,61116 & 0,009024 & 5 & 5 & $\mathbf{0 , 0 0 7 9 3 7}$ \\
\hline
\end{tabular}


Table 5S. Spearman correlation matrix of environmental parameters.

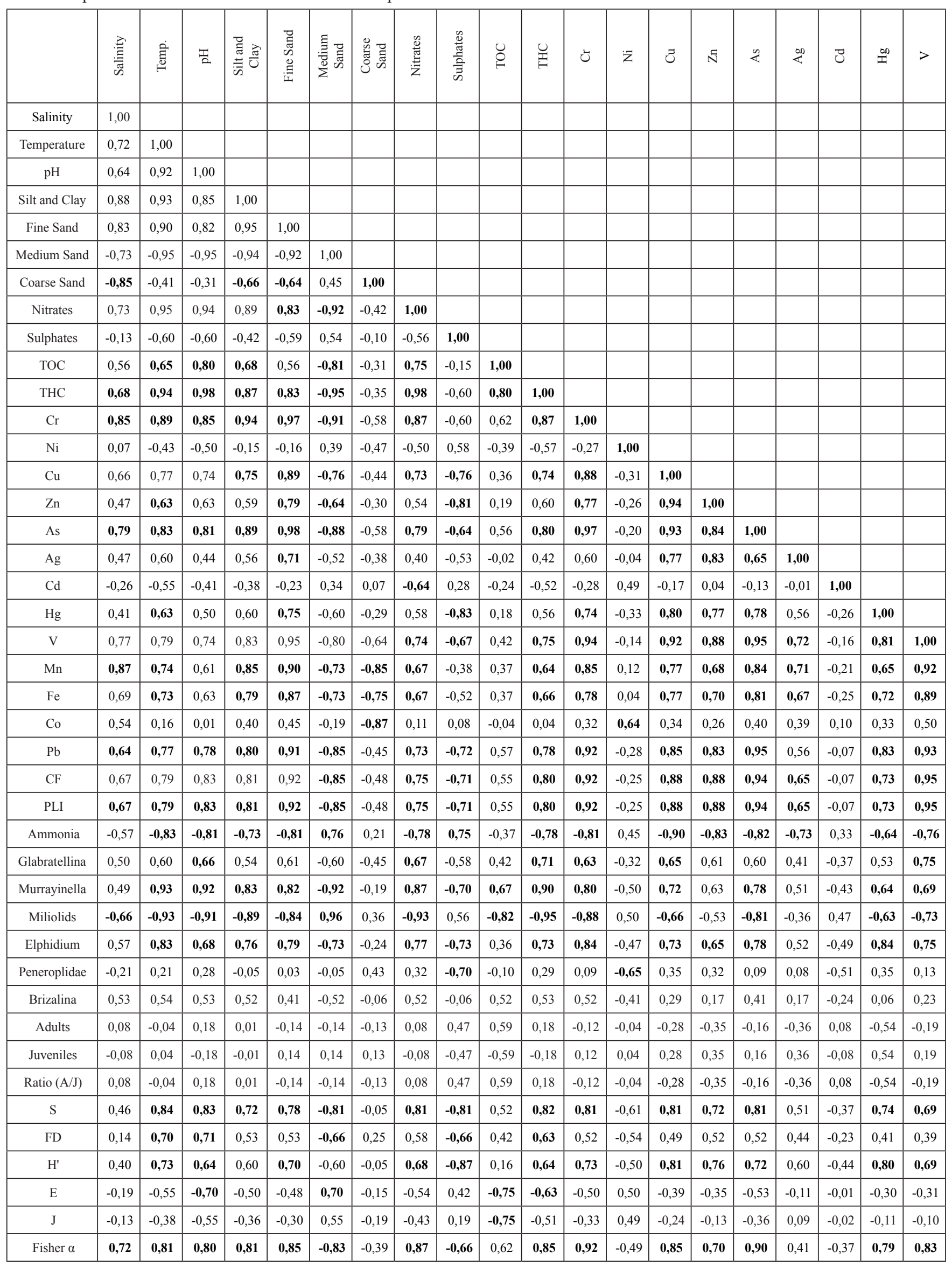

Spearman Rank Order Correlations (Data for Fabry.sta) MD pairwise deleted Marked correlations are significant at $\mathrm{p}<.05000$ 
Table 5S. Continued.

\begin{tabular}{|c|c|c|c|c|c|c|c|c|c|c|c|c|c|c|c|c|c|c|c|c|c|}
\hline$\sum^{\Xi}$ & 诖 & 8 & 2 & 崩 & $\vec{a}$ & 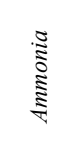 & 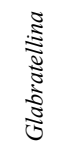 &  & $\begin{array}{l}\frac{n}{0} \\
: \frac{0}{5} \\
\Sigma\end{array}$ & 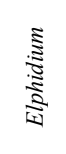 & 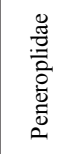 & 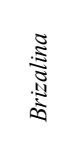 & $\frac{n}{\frac{n}{z}}$ & 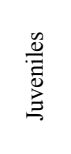 & 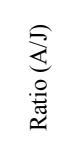 & is & 届 & i & 피 & $\sim$ & 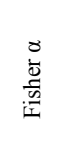 \\
\hline & & & & & & & & & & & & & & & & & & & & & \\
\hline & & & & & & & & & & & & & & & & & & & & & \\
\hline & & & & & & & & & & & & & & & & & & & & & \\
\hline & & & & & & & & & & & & & & & & & & & & & \\
\hline & & & & & & & & & & & & & & & & & & & & & \\
\hline & & & & & & & & & & & & & & & & & & & & & \\
\hline & & & & & & & & & & & & & & & & & & & & & \\
\hline & & & & & & & & & & & & & & & & & & & & & \\
\hline & & & & & & & & & & & & & & & & & & & & & \\
\hline & & & & & & & & & & & & & & & & & & & & & \\
\hline & & & & & & & & & & & & & & & & & & & & & \\
\hline & & & & & & & & & & & & & & & & & & & & & \\
\hline & & & & & & & & & & & & & & & & & & & & & \\
\hline & & & & & & & & & & & & & & & & & & & & & \\
\hline & & & & & & & & & & & & & & & & & & & & & \\
\hline & & & & & & & & & & & & & & & & & & & & & \\
\hline & & & & & & & & & & & & & & & & & & & & & \\
\hline & & & & & & & & & & & & & & & & & & & & & \\
\hline & & & & & & & & & & & & & & & & & & & & & \\
\hline & & & & & & & & & & & & & & & & & & & & & \\
\hline 1,00 & & & & & & & & & & & & & & & & & & & & & \\
\hline 0,94 & 1,00 & & & & & & & & & & & & & & & & & & & & \\
\hline 0,72 & 0,72 & 1,00 & & & & & & & & & & & & & & & & & & & \\
\hline $\mathbf{0 , 7 7}$ & $\mathbf{0 , 7 8}$ & 0,31 & 1,00 & & & & & & & & & & & & & & & & & & \\
\hline 0,81 & 0,81 & 0,30 & 0,96 & 1,00 & & & & & & & & & & & & & & & & & \\
\hline $\mathbf{0 , 8 1}$ & $\mathbf{0 , 8 1}$ & 0,30 & 0,96 & 1,00 & 1,00 & & & & & & & & & & & & & & & & \\
\hline$-0,59$ & $-0,56$ & $-0,04$ & $-0,71$ & $-0,76$ & $-0,76$ & 1,00 & & & & & & & & & & & & & & & \\
\hline $\mathbf{0 , 6 8}$ & 0,76 & 0,30 & 0,64 & 0,75 & 0,75 & $-0,48$ & 1,00 & & & & & & & & & & & & & & \\
\hline 0,56 & 0,64 & 0,02 & $\mathbf{0 , 7 8}$ & $\mathbf{0 , 7 7}$ & $\mathbf{0 , 7 7}$ & $-0,81$ & 0,50 & 1,00 & & & & & & & & & & & & & \\
\hline$-0,65$ & $-0,66$ & $-0,08$ & $-0,83$ & $-0,79$ & $-0,79$ & 0,67 & $-0,60$ & $-0,91$ & 1,00 & & & & & & & & & & & & \\
\hline 0,61 & 0,56 & 0,06 & \begin{tabular}{|l|}
0,78 \\
\end{tabular} & 0,71 & 0,71 & $-0,77$ & 0,43 & 0,77 & $-0,79$ & 1,00 & & & & & & & & & & & \\
\hline$-0,13$ & 0,02 & $-0,40$ & 0,10 & 0,14 & 0,14 & $-0,47$ & 0,36 & 0,29 & $-0,13$ & 0,33 & 1,00 & & & & & & & & & & \\
\hline 0,17 & $-0,06$ & $-0,36$ & 0,29 & 0,29 & 0,29 & $-0,52$ & $-0,06$ & 0,43 & $-0,52$ & 0,52 & $-0,06$ & 1,00 & & & & & & & & & \\
\hline$-0,09$ & $-0,08$ & $-0,09$ & $-0,14$ & $-0,05$ & $-0,05$ & 0,31 & 0,19 & $-0,06$ & $-0,12$ & $-0,48$ & $-0,36$ & 0,06 & 1,00 & & & & & & & & \\
\hline 0,09 & 0,08 & 0,09 & 0,14 & 0,05 & 0,05 & $-0,31$ & $-0,19$ & 0,06 & 0,12 & 0,48 & 0,36 & $-0,06$ & $-1,00$ & 1,00 & & & & & & & \\
\hline$-0,09$ & $-0,08$ & $-0,09$ & $-0,14$ & $-0,05$ & $-0,05$ & 0,31 & 0,19 & $-0,06$ & $-0,12$ & $-0,48$ & $-0,36$ & 0,06 & 1,00 & $-1,00$ & 1,00 & & & & & & \\
\hline 0,46 & 0,48 & $-0,12$ & 0,79 & 0,74 & 0,74 & $-0,91$ & 0,39 & $\mathbf{0 , 9 0}$ & $-\mathbf{0 , 8 1}$ & 0,87 & 0,47 & 0,56 & $-0,31$ & 0,31 & $-0,31$ & 1,00 & & & & & \\
\hline 0,18 & 0,22 & $-0,38$ & 0,53 & 0,54 & 0,54 & $-0,73$ & 0,14 & $\mathbf{0 , 8 5}$ & $-0,65$ & 0,64 & 0,35 & 0,52 & $-0,20$ & 0,20 & $-0,20$ & 0,83 & 1,00 & & & & \\
\hline 0,48 & 0,48 & $-0,04$ & $\mathbf{0 , 6 8}$ & 0,66 & 0,66 & $-\mathbf{0 , 8 9}$ & 0,41 & $\mathbf{0 , 7 3}$ & $-0,61$ & 0,90 & 0,61 & 0,41 & $-0,61$ & 0,61 & $-0,61$ & 0,91 & 0,70 & 1,00 & & & \\
\hline$-0,09$ & $-0,15$ & 0,32 & $-0,57$ & $-0,50$ & $-0,50$ & 0,52 & $-0,07$ & $-0,76$ & 0,68 & $-0,43$ & $-0,08$ & $-0,52$ & $-0,18$ & 0,18 & $-0,18$ & $-0,73$ & $-0,79$ & $-0,39$ & 1,00 & & \\
\hline 0,08 & 0,03 & 0,36 & $-0,36$ & $-0,27$ & $-0,27$ & 0,36 & 0,09 & $-0,58$ & 0,54 & $-0,24$ & $-0,02$ & $-0,52$ & $-0,31$ & 0,31 & $-0,31$ & $-0,58$ & $-0,60$ & $-0,20$ & 0,94 & 1,00 & \\
\hline 0,66 & 0,62 & 0,15 & 0,87 & $\mathbf{0 , 8 1}$ & $\mathbf{0 , 8 1}$ & $-0,79$ & 0,58 & 0,76 & $-0,84$ & 0,85 & 0,31 & 0,52 & $-0,16$ & 0,16 & $-0,16$ & 0,87 & 0,49 & $\mathbf{0 , 7 8}$ & $-0,55$ & $-0,45$ & 1,00 \\
\hline
\end{tabular}


Table 6S. Similarity percentages for abiotic factors calculated using SIMPER.

\begin{tabular}{|c|c|c|c|c|c|c|}
\hline & Group Polluted & Group Unpolluted & & & & \\
\hline Species & Av. Abund & Av. Abund & Av. Diss & Diss/SD & Contrib \% & Cum. $\%$ \\
\hline CF & 607,44 & 31,76 & 1,88 & 3,81 & 14,37 & 14,37 \\
\hline THC & 67,37 & 2,24 & 1,48 & 3,6 & 11,33 & 25,7 \\
\hline Sulphates & 1477,6 & 4231,2 & 1,42 & 23,61 & 10,85 & 36,55 \\
\hline Pb & 10,27 & 0,06 & 0,95 & 4,9 & 7,29 & 43,84 \\
\hline PLI & 309,75 & 72,69 & 0,95 & 4,29 & 7,27 & 51,11 \\
\hline TOC & 10447,6 & 7296,4 & 0,81 & 1,12 & 6,23 & 57,34 \\
\hline Cu & 41,9 & 3,45 & 0,74 & 1,62 & 5,69 & 63,03 \\
\hline Cr & 20,4 & 3,6 & 0,57 & 1,82 & 4,37 & 67,39 \\
\hline Hg & 54 & 12 & 0,55 & 1,44 & 4,23 & 71,62 \\
\hline Zn & 49,06 & 10,7 & 0,55 & 1,49 & 4,22 & 75,84 \\
\hline Mn & 77,6 & 27,6 & 0,52 & 1,48 & 3,97 & 79,81 \\
\hline V & 12,4 & 3,8 & 0,34 & 1,53 & 2,57 & 82,39 \\
\hline Water depth & 44,2 & 72,2 & 0,31 & 1,48 & 2,38 & 84,76 \\
\hline Coarse Sand & 6,72 & 8,4 & 0,29 & 1,32 & 2,23 & 86,99 \\
\hline Silt and Clay & 10,61 & 5,54 & 0,24 & 1,62 & 1,84 & 88,83 \\
\hline Nitrates & 196,46 & 0,94 & 8,48 & 1,77 & 90,61 \\
\hline A & & & & & \\
\hline
\end{tabular}

Average dissimilarity $=13.08$

Table 7S. Similarity percentages for biotic factors calculated using SIMPER.

\begin{tabular}{|c|c|c|c|c|c|c|}
\hline & Group Polluted & Group Unpolluted & & & & \\
\hline Species & Av. Abund & Av. Abund & Av. Diss & Diss/SD & Contrib \% & Cum. \% \\
\hline Murrayinella & 24,14 & 0 & 4,31 & 27,88 & 39,62 & 39,62 \\
\hline Miliolids & 1,75 & 28,3 & 2,31 & 7 & 21,18 & 60,8 \\
\hline FD & 254,4 & 153 & 1,07 & 1,35 & 9,85 & 70,65 \\
\hline Peneroplidae & 1,57 & 0,87 & 0,66 & 0,81 & 6,07 & 76,71 \\
\hline Elphidium & 6,71 & 3,34 & 0,49 & 2,16 & 4,54 & 81,25 \\
\hline Juveniles & 47,72 & 39,44 & 0,37 & 1,17 & 3,4 & 84,66 \\
\hline Brizalina & 0,06 & 0 & 0,29 & 0,49 & 2,66 & 87,32 \\
\hline Ratio (A/J) & 1,12 & 1,78 & 0,28 & 1,17 & 2,54 & 89,86 \\
\hline Adults & 52,28 & 60,56 & 0,27 & 1,31 & 2,48 & 92,34 \\
\hline
\end{tabular}

Average dissimilarity $=10.89$

\section{References}

1. ARMYNOT DU CHÂTELET É., DEBENAY J.-P. The anthropogenic impact on the western French coasts as revealed by foraminifera: a review. Revue de Micropaléontologie, $\mathbf{5 3}$ (3), 129, 2010

2. FRONTALINI F., COCCIONI R. Benthic foraminifera as bioindicators of pollution: a review of Italian research over the last three decades. Revue de Micropaléontologie, 54 (2), 115, 2011.
3. UTHICKE S., THOMPSON A., SCHAFFELKE B. Effectiveness of benthic foraminiferal and coral assemblages as water quality indicators on inshore reefs of the Great Barrier Reef, Australia. Coral Reefs, 29 (1), 2095, 2010.

4. GOODAY A.J., JORISSEN F.J. Benthic foraminiferal biogeography: controls on global distribution patterns in deep-water settings. Annual Review of Marine Science, 4, 237, 2012.

5. FRONTALINI F., BUOSI C., DA PELO S., COCCIONI R., CHERCHI A., BUCCI C. Benthic foraminifera as 
bio-indicators of trace element pollution in the heavily contaminated Santa Gilla lagoon (Cagliari, Italy). Marine Pollution Bulletin, 58 (6), 858, 2009.

6. FRONTALINI F., COCCIONI R. Benthic foraminifera for heavy metal pollution monitoring: a case study from the central Adriatic Sea coast of Italy. Estuarine, Coastal and Shelf Science, 76 (2), 404, 2008.

7. DESSANDIER P.-A., BONNIN J., KIM J.-H., BICHON S., GRÉMARE A., DEFLANDRE B., DE STIGTER H., MALAIZÉ B. Lateral and vertical distributions of living benthic foraminifera off the Douro River (western Iberian margin): Impact of the organic matter quality. Marine Micropaleontology, 120, 31, 2015.

8. MARTINS M.V.A., ZAABOUB N., ALEYA L., FRONTALINI F., PEREIRA E., MIRANDA P., MANE M., ROCHA F., LAUT L., EL BOUR M. Environmental quality assessment of Bizerte Lagoon (Tunisia) using living foraminifera assemblages and a multiproxy approach. PloS one, 10 (9), e $0137250,2015$.

9. MARTINS V.A., FRONTALINI F., TRAMONTE K.M., FIGUEIRA R.C., MIRANDA P., SEQUEIRA C., FERNÁNDEZ-FERNÁNDEZ S., DIAS J.A., YAMASHITA C., RENÓ R. Assessment of the health quality of Ria de Aveiro (Portugal): heavy metals and benthic foraminifera. Marine Pollution Bulletin, 70 (1), 18, 2013.

10. SCHMIEDL G., MACKENSEN A., MÜLLER P. Recent benthic foraminifera from the eastern South Atlantic Ocean: dependence on food supply and water masses. Marine Micropaleontology, 32 (3), 249, 1997.

11. JORISSEN F., BICCHI E., DUCHEMIN G., DURRIEU J., GALGANI F., CAZES L., GAULTIER M., and CAMPS R. Impact of oil-based drill mud disposal on benthic foraminiferal assemblages on the continental margin off Angola. Deep Sea Research Part II: Topical Studies in Oceanography, 56 (23), 2270, 2009.

12. MOJTAHID M., JORISSEN F., PEARSON T. Comparison of benthic foraminiferal and macrofaunal responses to organic pollution in the Firth of Clyde (Scotland). Marine Pollution Bulletin, 56 (1), 42, 2008.

13. ASHCKENAZI-POLIVODA S., EDELMAN-FURSTENBERG Y., ALMOGI-LABIN A., BENJAMINI C. Characterization of lowest oxygen environments within ancient upwelling environments: Benthic foraminifera assemblages. Palaeogeography, Palaeoclimatology, Palaeoecology, 289 (1), 134, 2010.

14. DAUVIN J.-C., BELLAN G., BELLAN-SANTINI D. Benthic indicators: From subjectivity to objectivity - Where is the line? Marine Pollution Bulletin, 60 (7), 947, 2010.

15. DENOYELLE M., JORISSEN F.J., MARTIN D., GALGANI F., MINÉ J. Comparison of benthic foraminifera and macrofaunal indicators of the impact of oil-based drill mud disposal. Marine Pollution Bulletin, 60 (11), 2007, 2010.

16. ARSLAN M., KAMINSKI M.A., TAWABINI B.S., ILYAS M., BABALOLA L.O., FRONTALINI F. Seasonal variations, environmental parameters, and standing crop assessment of benthic foraminifera in eastern Bahrain, Arabian Gulf. Geological Quarterly, 59 (4),doi: 10.7306/gq. 1242, 2016.

17. WILSON M.B., ZHANG C.C., GANDHI J. Analysis of inorganic nitrogen and related anions in high salinity water using ion chromatography with tandem UV and conductivity detectors. Journal of Chromatographic Science, 49 (8), 596, 2011.

18. ARSLAN M., KAMINSKI M.A., KHALIL A.B. Living Behaviors of Benthic Foraminifera from Eastern Bahrain and the Saudi Coastline. Bulletin of Environmental Studies, 1 (1), 1, 2016.

19. HOTTINGER L., HALICZ E.R., REISS Z. Recent Foraminiferida from the Gulf of Aqaba, Red Sea. Dela Slovenska Akademija Znanosti in Umetnosti, 33, 1, 1993.

20. LOEBLICH A.R., TAPPAN H.N., Foraminifera of the Sahul shelf and Timor Sea. 1994: Cushman Foundation for Foraminiferal Research Special Publication, 31, 1, 1994.

21. HAYWARD B.W., HOLZMANN M., GRENFELL H.R., PAWLOWSKI J., TRIGGS C.M. Morphological distinction of molecular types in Ammonia-towards a taxonomic revision of the world's most commonly misidentified foraminifera. Marine Micropaleontology, 50 (3), 237, 2004.

22. RIAZ M., MAHMOOD T., ARSLAN M. Non-Parametric versus Parametric Methods in Environmental Sciences. Bulletin of Environmental Studies, 1 (1), 3, 2016.

23. ANTONIADIS V., KOUTROUBAS S., FOTIADIS S. Nitrogen, Phosphorus, and Potassium Availability in Manure-and Sewage Sludge-Applied Soil. Communications in Soil Science and Plant Analysis, 46 (3), 393, 2015.

24. GOODAY A., LEVIN L., DA SILVA A.A., BETT B., COWIE G., DISSARD D., GAGE J., HUGHES D., JEFFREYS R., LAMONT P. Faunal responses to oxygen gradients on the Pakistan margin: A comparison of foraminiferans, macrofauna and megafauna. Deep Sea Research Part II: Topical Studies in Oceanography, 56 (6), 488, 2009.

25. 25. MARTINS V., YAMASHITA C., SOUSA S., MARTINS P., LAUT L., FIGUEIRA R., MAHIQUES M., DA SILVA E.F., DIAS J.A., ROCHA F. The response of benthic foraminifera to pollution and environmental stress in Ria de Aveiro (N Portugal)/La respuesta de los foraminíferos bentónicos a la contaminación y el estrés ambiental en la Ría de Aveiro ( $\mathrm{N}$ de Portugal). Journal of Iberian Geology, 37 (2), 231, 2011.

26. DEBENAY J.-P., TSAKIRIDIS E., SOULARD R., GROSSEL H. Factors determining the distribution of foraminiferal assemblages in Port Joinville Harbor (Ile d'Yeu, France): the influence of pollution. Marine Micropaleontology, 43 (1), 75, 2001.

27. MELIS R., VIOLANTI D. Foraminiferal biodiversity and Holocene evolution of the Phetchaburi coastal area (Thailand Gulf). Marine Micropaleontology, 61 (1), 94, 2006.

28. MOSSADEGH Z.K., PARKER J., GISCHLER E. Biodiversity and community structure of Late Pleistocene foraminifera from Kish Island, Persian Gulf (Iran). Facies, 58 (3), 339, 2012.

29. CHERIF O.H., AL-GHADBAN A.-N., AL-RIFAIY I.A. Distribution of foraminifera in the Arabian Gulf. Micropaleontology, 43 (3), 253, 1997.

30. SAIDOVA K.M. Benthic foraminifer communities of the Persian Gulf. Oceanology, 50 (1), 61, 2010.

31. CHIVAS A.R., GARCíA A., VAN DER KAARS S., COUAPEL M.J., HOLT S., REEVES J.M., WHEELER D.J., SWITZER A.D., MURRAY-WALLACE C.V., BANERJEE D. Sea-level and environmental changes since the last interglacial in the Gulf of Carpentaria, Australia: an overview. Quaternary International, 83, 19, 2001.

32. PARKER J.H. Taxonomy of foraminifera from Ningaloo Reef, Western Australia. Australasian Palaeontological Memoirs, 36, 1, 2009.

33. NOMURA R., TAKAYANAGI Y. The suprageneric classification of the foraminiferal genus Murrayinella and a new species from Japan. Paleontological Research, 4 (3), 171, 2000. 
34. FRONTALINI F., MARGARITELLI G., FRANCESCANGELI F., RETTORI R., DU CHÂTELET E.A., COCCIONI $\mathrm{R}$. Benthic foraminiferal assemblages and biotopes in a coastal lake: the case study of Lake Varano (southern Italy). Acta Protozoologica, 52 (3), 147, 2013.

35. HYAMS-KAPHZAN O., ALMOGI-LABIN A., BENJAMINI C., HERUT B. Natural oligotrophy vs. pollution-induced eutrophy on the SE Mediterranean shallow shelf (Israel): Environmental parameters and benthic foraminifera. Marine Pollution Bulletin, 58 (12), $1888,2009$.

36. PLATON E., GUPTA B.K.S., RABALAIS N.N., TURNER R.E. Effect of seasonal hypoxia on the benthic foraminiferal community of the Louisiana inner continental shelf: the 20th century record. Marine Micropaleontology, 54 (3), 263, 2005. 